\title{
Assessment of Health-related Locus of Control among Undergraduates Substance Users and Non-Users
}

\author{
Adekeye, Olujide A. ${ }^{\text {,c }}$, Agoha, Ben C. ${ }^{\text {, }}$, Adeusi, Sussan O. ${ }^{\text {b }}$ Igbokwe, David \\ O. ${ }^{a}$, Olowookere, Elizabeth I. ${ }^{a}$, Elegbeleye, Ayo O. ${ }^{a}$ and Sholarin, Muyiwa A. ${ }^{a}$ \\ a. Clinical Psychologist, Covenant University, Ota, Nigeria \\ b. Counselling Psychologist, Covenant University, Ota, Nigeria \\ c. Sexual Health Advocate (HIV/AIDS), Covenant University, Ota, Nigeria
}

\begin{abstract}
Introduction: Locus of control is one of the most extensively investigated psychological constructs in literature and the purpose of the study was to assess health-related locus of control among undergraduate's substance users and non-users.

Methods: Data from 574 students between ages 18 and $27(n=574$, mean=21.15 (+/- 1.8years) was collected from five tertiary institutions in AdoOdo-Ota LGA, Nigeria. An adapted and validatedversion of the World Health Organization (WHO) questionnaire on drug use surveys and the multidimensional health locus of control (MHLC) which was designed to measure the degree to which an individual feels they are in control of their ownhealth were employed for data collection. Data collected were analyzed using descriptive and inferentialstatistics.Three research hypotheses were raised and tested. Data collected were analyzed using descriptive and inferential statistics.

Results: The preliminary result shows that there is no significant difference in the health-related locus of control between substance users and non-users, and between heavy and occasional drinkers, but there exist significant differences based on gender.

Conclusion: This article discusses the implications of these findings especially in the area of health education and the use of health locus of control measures
\end{abstract}

Keywords: health, locus of control, substance use, students, tertiary institutions

\section{INTRODUCTION}

Locus of control originated with Rotter's social learning theory (Rotter, 1966) and it is the beliefs that individuals hold regarding the relationships between action and outcome (Rotter, 1990; Lefcourt, 1991). Rotter defines internal versus external control as "the degree to which persons expect that a reinforcement or an outcome of their behaviour is contingent on their own behaviour or personal characteristics versus the degree to which persons expect that reinforcement is a function of chance, luck or fate, is under the control of powerful others, or is simply unpredictable" (1990, p. 489).The first commonly used LOC scale was developed by Rotter in 1966, called the Internal-External Locus of Control Scale (I-E). This assesses the degree to which people perceive the consequences of their behaviour to be under the control of internal or external variables. Locus of control is one of the most extensively investigated constructs in psychological and social science literature (Carton \& Nowicki, 1994; Rotter, 1990) and of potential use for substance abuse researchers and treatment practitioners.

People having internal orientations are more likely to be aware of and to use good health practices. Health is one of the many areas in which there has been a significantamount of interest in relating locus of control beliefs to a varietyof relevant behaviours. The prevalence rates of alcohol, tobacco, and marijuana use typically increase over the adolescent years and reach a peak during late adolescence and early adulthood. Alcohol use is the most prevalent substance use behaviour among teens, and marijuana is the most prevalent illicit drug used (Adekeye, Adeusi, Chenube, Ahmadu \& Sholarin, 2015). These rates of use are alarming in light of the many serious consequences of adolescent substance use, which include a range of health, social, psychological, and neurocognitive problems that can interfere with normative development (Newcomb\& Locke, 2005).Alcohol and marijuana use during adolescence contribute to a variety of negative outcomes including unintentional injuries and deaths, traffic fatalities, risky sexual behaviours, school dropout, interpersonal aggression, and psychiatric problems (Danielsson, Wennberg, Tengstrom \& Romelsjo, 2010; Hingson, Zha \& Weitzman, 2009; Miller, Naimi, Brewer\& Jones, 2007; Townsend, Flisher\&King, 2007). 
Substance abuse remains an important problem in Nigeria, as well as in many countries around the world. Typically substance use begins during the early teen years and progresses from non-use, to occasional use and to the frequent use of one or more substances. Substance use occurs on a spectrum such as from experimentation to dependence. Adolescents start on alcohol say out of curiosity and because it feels good, reduces stress, and helps to feel grown up may continue use after the initial experimentation. In addition, adolescents may abuse drugs fora variety of reasons and their individual and environmentalstatus impacts on drug abuse related behaviours (Allahverdipour, MacIntyre, Hidarnia,Shafii, Kazemnegad, Geleiha\&Emami, 2007). A number of studies emphasize on longitudinal studies to examine patterns ofsubstance use among adolescents over time (Sneed, Morisky, Rotheram-Borus, Ebin \& Malotte, 2001).As a result, by examining substance abuse overtime, the nature of chronic use and transition to more illicit substance use can more accurately becharacterized.

The use of substances especially alcohol, cigarettes and marijuana has become prevalent among Nigerian high school and undergraduate students. Young people (ages 18 to 24) are already at a heightened risk of addiction. Hence, it can be evidently established that students make up one of the largest groups of substance users and abusers globally. Starting out in college produces some natural social anxiety for many students. The temptation to drink is strong because college students overwhelmingly find that alcohol makes socializing easier. Not all college students immediately start binge drinking and doing drugs, but routinely drinking to have more fun leads many students toward addiction. Peer pressure is often cited as an important factor in adolescents' substance use and abuse.

In examining the correlates of early alcohol use by adolescents, Jessor,Collins\& Jessor (1972) found that an internal-external locus of control scale did not predict adolescentsat risk for alcohol use/misuse. In contrast, Currie,Perlman\&Walker (1977) found thatinternally oriented youths were less likely to use marijuana than were externally orientedyouths. Similarly, Clarke, MacPherson \& Holmes (1982) found adolescents' past and present useof cigarettes and intentions to use cigarettes to be modestly related to an external viewof control.

However, one consistent criticism of the instrumentation of early locus of control (LOC) research is that LOC was treated as a unidimensional construct (Rotter, 1975; Lefcourt, 1982, 1991). As a result of this criticism, researchers took two approaches: (1) was creating the multidimensional instruments, for example the Internality, Powerful Others, and Chance Scales (Levenson,1981) and the Multidimensional Health Locus of Control Scale (Wallston \& Wallston, 1981); and (2) create instruments targeted toward specific aspects of control, such as, the Marital Locus of Control Scale (Miller, Lefcourt \& Ware, 1983) and the Mental Health Locus of Control Scale (Hill \& Bale, 1980).

Health locus of control (HLC) is a construct that refers to how individuals perceive the sources regulating their health (Wallston, Wallston \& DeVellis, 1978).Older HLC studies have also highlighted population differences in health beliefs. Previous research has shown that low socioeconomic status, female sex, non-white ethnicity, old age and low education are associated with increased external health locus of control (EHLC) (Cohen\& Azaiza, 2007; Spalding, 1995).Health locus of control is considered to involvethree statistically independent dimensions of perceivedcontrol in relation to health: Internal, Chanceand Powerful Others (Wallston et al., 1978). Individuals'who score highly on the internal dimensionregard their health as largely within their owncontrol and are likely to engage in health maintainingbehaviours. Conversely, those who scorehighly on the Chance dimension view their healthas relatively independent of their behaviour and,accordingly, are more likely to engage in healthdamagingbehaviours than those with lower scores.

The implications of a strong belief in PowerfulOthers (typically doctors) influencing health are more difficult to predict. High ratings may indicatereceptivity to health messages endorsed by medicalauthorities. Conversely, they may suggest astrong belief in the ability of the medical systemto cure any relevant illness. Each would result indifferent patterns of health-related behaviours.Individuals' perceived control over their health has been examined extensivelyto discover the nature and extent of its relationship to health knowledge, health behaviour, and health status. Given the influence of conformityto peer norms for substance use behaviour among adolescents and youngadults, perceived control over health status is a relevant factor to investigate. This study was designed and intended to provide an understanding of the concept of health locus of control (HLOC) as it relates to substance users and non-users. This understanding may assist in the design of intervention strategies to mitigate substance abuse and consequent substance dependence. Also, this study will unravel the health locus of control beliefs of undergraduate substance users and by extension that of non-substance users.

\section{Research Hypotheses}

1. Stimulant users subscribe to internality

2. There is a significant difference between the HLOC of stimulant users and non-users

\section{METHODS}




\section{Design/Population/Sample and Sampling Techniques}

The design used for this study is the survey research design. This study involved participants from some selected universities in Ogun State, Nigeria. We selected participants from the humanities, social sciences, physical and natural sciences, engineering, marketing and agriculture through stratified and simple random sampling, to cater for variables such as gender, faculty and university. This initial selection generated a pool of 675 participants. Seventy-seven (77) declined participation while some questionnaire forms were not properly filled. At the end, only 574 of the 598 questionnaire forms were properly filled and fit for use constituting $96 \%$ response rate.Characteristics of the participants included a gender mix of 413 males (72\%) and 161 females (28\%), age ranges from 18 and 27 years (mean age $=21.15,+/-1.8$ years). All the participants indicated they were single.

\section{Ethical Consideration}

Prior to administering the questionnaire, the purpose of the study was explained to the participants. Participation was voluntary and there was no incentive given for participation. Those who agreed to participate were made to sign a consent form. Anonymity was assured by asking participants not to write their names on the questionnaire forms.

\section{Instruments}

A questionnaire consisting of two validated scales was used.The first part of thequestionnaire dealt with participants socio-demographic details while the second part was divided into sections A and B. Section A has the adaptedWorld Health Organization (WHO) questionnaire designed for drug study among student populationwhile section B measured Health Locus of Controlusing the 18-item Multidimensional Health Locus of Control (MHLC).The Multidimensional Health Locus of Control (MHLC) Scales are a family of measures developed by Wallston and colleagues. These scales are designedto assess a person's beliefs regarding whether his or her healthstatus is determined by the actions of individuals (as opposedto fate, luck, or chance) and, if so, whether the locus of thatcontrol is "internal" (i.e., residing in the person's own actions)or "external" (i.e., dependent on the actions of other people).The three MHLC subscales areInternal Health Locus of Control (IHLC, e.g., "The main thing that affects my health is what Imyself do"), PHLC (e.g., "My family has a lot to do with mybecoming sick or staying healthy"), and CHLC (e.g., "If it ismeant to be, I will stay healthy"). In most populations, IHLCand PHLC are uncorrelated with each other, IHLC and CHLCare slightly negatively intercorrelated (-.lo to -.20), and thetwo external dimensions, PHLC and CHLC, are somewhatpositively intercorrelated (.20 to .30). The alpha reliabilitiesof the six-item subscales hover around .70 (.65-.75), and thetest-retest reliabilities are in the range of .70-30.The reliability and validity of the MHLC is not in question because the scale has been widely used and validated, but for the purpose of this study, the MHLC returned a coefficient reliability of 0.74 using a test-retest reliability method.The Cronbach's alpha for the three subscales yielded a coefficient of $0.75,0.71$ and 0.69for InternalHLC, Powerful Others HLC, andChance HLC respectively.

\section{Procedure for Data collection and Analysis}

The questionnaire forms were administeredto the participants with the aid of graduatestudents who were trained as researchassistants. The questionnaires wereadministered and some were collected on the spot while others were retrieved later. Five hundred and seventy-four forms were fit for statistical analyses, representing $96 \%$ response rate. The data were expressedas both descriptive and inferentialstatistics, such as frequency counts, percentages and chi-square analysis to test the hypotheses. A p-value of $\leq 0.05$ was considered significant. Allstatistical analyses were performed using IBM statistical software.

\section{RESULTS}

Hypothesis 1: Stimulants Users Display Internal Health Locus of Control. This was done by Analyzing the Responses of Stimulants Users and non-Users to the three Sub-Scales of the MHLC

Table 1: Analysis of the Responses of Stimulants Users and non-Users to the Internal Health Locus of Control (IHLC) Scale

\begin{tabular}{|l|l|l|l|l|l|l|l|}
\hline S/N & ITEMS & & Users & N. Users & Total & $\mathbf{X}^{2}$ & Rem \\
\hline \multirow{2}{*}{1} & $\begin{array}{l}\text { If I become sick, I have } \\
\text { the power to make myself } \\
\text { well again. }\end{array}$ & Int & $287(68.5)$ & $101(65.2)$ & $388(67.6)$ & .58 & NS \\
\cline { 2 - 6 } 6 & $\begin{array}{l}\text { I am directly responsible } \\
\text { for my health }\end{array}$ & Int & $342(31.5)$ & $54(34.8)$ & $186(32.4)$ & & \\
\cline { 2 - 6 } & Ext & $79(18.9)$ & $129(83.2)$ & $469(81.7)$ & .33 & NS \\
\hline 8 & Whatever goes wrong & Int & $247(58.9)$ & $95(61.3)$ & $342(59.6)$ & .26 & NS \\
\hline
\end{tabular}




\begin{tabular}{|l|l|l|l|l|l|l|l|}
\hline & $\begin{array}{l}\text { with my health is my own } \\
\text { fault }\end{array}$ & Ext & $172(41.1)$ & $60(38.7)$ & $232(40.4)$ & & \\
\hline 12 & $\begin{array}{l}\text { My physical well-being } \\
\text { depends on how well I } \\
\text { take care of myself }\end{array}$ & Ext & $375(89.5)$ & $136(87.7)$ & $511(89.0)$ & .36 & NS \\
\hline 13 & \begin{tabular}{l} 
When I feel ill I know it \\
is because I have not been \\
\cline { 2 - 7 } \\
taking care of myself \\
properly
\end{tabular} & Ext & $197(47.0)$ & $77(49.7)$ & $274(47.7)$ & .32 & NS \\
\hline 17 & $\begin{array}{l}\text { I can pretty much stay } \\
\text { healthy by taking good } \\
\text { care of myself }\end{array}$ & Int & $364(86.9)$ & $136(87.7)$ & $500(87.1)$ & $.05^{*}$ & $\mathrm{~S}$ \\
\hline
\end{tabular}

\section{*: Significant at 0.05 level; NS: Statistically not significant}

Tables 1 to 3 showthe comparison of responses for both stimulant users and non-users on the multidimensional health locus of control (MHLC). Table 1 compares participants' responses to the internal health locus of control (IHLC) scale and the table revealed that in items 6, 8 and 17, non-substance users scored higher percentage in internality than substance users. Conversely, items 1, 12, and 13show stimulant users recording higher percent of "internalizers".

Table 2: Analysis of the Responses of Stimulants Users and non-Users to the Chance Health Locus of Control (CHLC) Scale

\begin{tabular}{|c|c|c|c|c|c|c|c|}
\hline $\mathrm{S} / \mathrm{N}$ & ITEMS & & Users & N. Users & Total & $\mathbf{X}^{2}$ & Rem \\
\hline \multirow[t]{2}{*}{2} & \multirow{2}{*}{$\begin{array}{l}\text { Often I feel that no matter } \\
\text { what I do I will get sick if I } \\
\text { am going to get sick }\end{array}$} & Int & $100(23.9)$ & $35(22.6)$ & $135(23.5)$ & \multirow[t]{2}{*}{.10} & \multirow[t]{2}{*}{$\mathrm{NS}$} \\
\hline & & Ext & $319(76.1)$ & $120(77.4)$ & $439(76.5)$ & & \\
\hline \multirow[t]{2}{*}{4} & \multirow{2}{*}{$\begin{array}{l}\text { It seems that my health is } \\
\text { greatly influenced by } \\
\text { accidental happenings }\end{array}$} & Int & $79(18.9)$ & $33(21.3)$ & $112(19.5)$ & \multirow[t]{2}{*}{.43} & \multirow[t]{2}{*}{ NS } \\
\hline & & Ext & $340(81.1)$ & $122(78.7)$ & $462(80.5)$ & & \\
\hline \multirow[t]{2}{*}{9} & \multirow{2}{*}{$\begin{array}{l}\text { When I am sick, I just have to } \\
\text { let nature run its own course }\end{array}$} & Int & $93(22.2)$ & $31(20.0)$ & $124(21.6)$ & \multirow[t]{2}{*}{.32} & \multirow[t]{2}{*}{ NS } \\
\hline & & Ext & $326(77.8)$ & $124(80.0)$ & $450(78.4)$ & & \\
\hline \multirow[t]{2}{*}{11} & \multirow{2}{*}{$\begin{array}{l}\text { When I stay healthy I'm just } \\
\text { plain lucky }\end{array}$} & Int & $76(18.1)$ & $25(16.1)$ & $101(17.6)$ & \multirow[t]{2}{*}{.31} & \multirow[t]{2}{*}{ NS } \\
\hline & & Ext & $343(81.9)$ & $130(83.9)$ & $473(82.4)$ & & \\
\hline \multirow[t]{2}{*}{15} & \multirow{2}{*}{$\begin{array}{l}\text { Even when I take care of } \\
\text { myself it is easy to get sick }\end{array}$} & Int & $69(16.5)$ & $17(11.0)$ & $86(15.0)$ & \multirow[t]{2}{*}{2.69} & \multirow[t]{2}{*}{ NS } \\
\hline & & Ext & $350(83.5)$ & $138(89.0)$ & $488(85.0)$ & & \\
\hline \multirow[t]{2}{*}{16} & \multirow{2}{*}{$\begin{array}{l}\text { When I become ill it's a } \\
\text { matter of fate }\end{array}$} & Int & $82(19.6)$ & $33(21.3)$ & $115(20.0)$ & \multirow[t]{2}{*}{.21} & \multirow[t]{2}{*}{ NS } \\
\hline & & Ext & $337(80.4)$ & $122(78.7)$ & $457(80.0)$ & & \\
\hline
\end{tabular}

*: Significant at 0.05 level; NS: Statistically not significant

In Table 2, the comparison of chance health locus of control (CHLC) scale was presented. In items 2, 9, 11 and 15 , non-substance users scored higher percentage in externalities than substance users while substance users scored higher percentage in items 4 and 16.

Table 3: Analysis of the Responses of Stimulants Users and non-Users to the Powerful Others Health Locus of Control (PHLC) Scale

\begin{tabular}{|c|c|c|c|c|c|c|c|}
\hline S/N & ITEMS & & Users & N. Users & Total & $\mathbf{X}^{2}$ & Rem \\
\hline \multirow[t]{2}{*}{3} & \multirow{2}{*}{$\begin{array}{l}\text { If I see an excellent doctor } \\
\text { regularly, I am less likely to } \\
\text { have a health problem }\end{array}$} & Int & $216(51.6)$ & $79(51.0)$ & $295(51.4)$ & \multirow[t]{2}{*}{$.02 *$} & \multirow[t]{2}{*}{$\mathrm{S}$} \\
\hline & & Ext & $203(48.4)$ & $76(49.0)$ & $279(48.6)$ & & \\
\hline \multirow[t]{2}{*}{5} & \multirow{2}{*}{$\begin{array}{l}\text { I can only maintain my health } \\
\text { by consulting } \\
\text { professionals }\end{array}$} & Int & $85(20.3)$ & $40(25.8)$ & $125(21.8)$ & \multirow[t]{2}{*}{2.02} & \multirow[t]{2}{*}{ NS } \\
\hline & & Ext & 334(79.7) & $115(74.2)$ & $449(78.2)$ & & \\
\hline \multirow[t]{2}{*}{7} & \multirow{2}{*}{$\begin{array}{l}\text { Other people play a big part } \\
\text { whether I stay healthy or } \\
\text { become sick }\end{array}$} & Int & $159(37.9)$ & $50(32.3)$ & $209(36.4)$ & \multirow[t]{2}{*}{1.58} & \multirow[t]{2}{*}{ NS } \\
\hline & & Ext & $260(62.1)$ & $105(67.7)$ & $365(63.6)$ & & \\
\hline 10 & Health professionals keep me & Int & $126(30.1)$ & $46(29.7)$ & $172(30.0)$ & .08 & NS \\
\hline
\end{tabular}




\begin{tabular}{|c|c|c|c|c|c|c|c|}
\hline & healthy & Ext & $293(69.9)$ & $109(70.3)$ & $402(70.0)$ & & \\
\hline \multirow[t]{2}{*}{14} & The type of care I receive from & Int & $187(44.6)$ & $61(39.4)$ & $248(43.2)$ & \multirow[t]{2}{*}{1.28} & \multirow[t]{2}{*}{ NS } \\
\hline & $\begin{array}{l}\text { other people is what is } \\
\text { responsible for how well I } \\
\text { recover from an illness }\end{array}$ & Ext & $232(55.4)$ & $94(60.6)$ & $326(56.8)$ & & \\
\hline \multirow[t]{2}{*}{18} & \multirow{2}{*}{$\begin{array}{l}\text { Following doctor's orders to the } \\
\text { letter is the best way for me to } \\
\text { stay healthy }\end{array}$} & Int & $242(57.8)$ & $96(61.9)$ & $338(58.9)$ & \multirow[t]{2}{*}{.82} & \multirow[t]{2}{*}{ NS } \\
\hline & & Ext & $177(42.2)$ & $59(38.1)$ & $236(41.1)$ & & \\
\hline
\end{tabular}

\section{*: Significant at 0.05 level; NS: Statistically not significant}

Table 3 compares participants' responses to the powerful othershealth locus of control (PHLC) scale and the table revealed that substance users scored higher percentage in externalities than non-substance users in items 5 and 18. Conversely, items 3, 7, 10 and 14 show non-substance users recording higher percentage of external health locus of control.

Hypothesis2: There is a significant difference between the Health Locus of Control(HLOC) of Substance Users and Non- Substance Users

Table 4: Comparative Analysis of Substance Users and Non-SubstanceUsers

\begin{tabular}{|c|c|c|c|c|c|c|c|}
\hline $\mathrm{S} / \mathrm{N}$ & ITEMS & & Users & N. Users & Total & $\mathbf{X}^{2}$ & Sig. \\
\hline \multirow[t]{2}{*}{1} & \multirow{2}{*}{$\begin{array}{l}\text { If I become sick, I have the } \\
\text { power to make myself well } \\
\text { again. }\end{array}$} & Int & $287(68.5)$ & $101(65.2)$ & $388(67.6)$ & \multirow[t]{2}{*}{.58} & \multirow[t]{2}{*}{$\mathrm{NS}$} \\
\hline & & Ext & $132(31.5)$ & $54(34.8)$ & $186(32.4)$ & & \\
\hline \multirow[t]{2}{*}{2} & \multirow{2}{*}{$\begin{array}{l}\text { Often I feel that no matter } \\
\text { what I do I will get sick if I } \\
\text { am going to get sick }\end{array}$} & Int & $100(23.9)$ & $35(22.6)$ & $135(23.5)$ & \multirow[t]{2}{*}{.10} & \multirow[t]{2}{*}{ NS } \\
\hline & & Ext & $319(76.1)$ & $120(77.4)$ & $439(76.5)$ & & \\
\hline \multirow[t]{2}{*}{3} & \multirow{2}{*}{$\begin{array}{l}\text { If I see an excellent doctor } \\
\text { regularly, I am less likely to } \\
\text { have a health problem }\end{array}$} & Int & $216(51.6)$ & $79(51.0)$ & $295(51.4)$ & \multirow[t]{2}{*}{$.02 *$} & \multirow[t]{2}{*}{$\mathrm{S}$} \\
\hline & & Ext & $203(48.4)$ & $76(49.0)$ & $279(48.6)$ & & \\
\hline \multirow[t]{2}{*}{4} & \multirow{2}{*}{$\begin{array}{l}\text { It seems that my health is } \\
\text { greatly influenced by } \\
\text { accidental happenings }\end{array}$} & Int & $79(18.9)$ & $33(21.3)$ & $112(19.5)$ & \multirow[t]{2}{*}{.43} & \multirow[t]{2}{*}{ NS } \\
\hline & & Ext & $340(81.1)$ & $122(78.7)$ & $462(80.5)$ & & \\
\hline \multirow[t]{2}{*}{5} & \multirow{2}{*}{$\begin{array}{l}\text { I can only maintain my } \\
\text { health by consulting health } \\
\text { professionals }\end{array}$} & Int & $85(20.3)$ & $40(25.8)$ & $125(21.8)$ & \multirow[t]{2}{*}{2.02} & \multirow[t]{2}{*}{ NS } \\
\hline & & Ext & $334(79.7)$ & $115(74.2)$ & $449(78.2)$ & & \\
\hline \multirow[t]{2}{*}{6} & \multirow{2}{*}{$\begin{array}{l}\text { I am directly responsible for } \\
\text { my health }\end{array}$} & Int & $340(81.1)$ & $129(83.2)$ & $469(81.7)$ & .33 & $\mathrm{NS}$ \\
\hline & & Ext & 79(18.9) & $26(16.8)$ & $105(18.3)$ & & \\
\hline \multirow[t]{2}{*}{7} & \multirow{2}{*}{$\begin{array}{l}\text { Other people play a big part } \\
\text { whether I stay healthy or } \\
\text { become sick }\end{array}$} & Int & $159(37.9)$ & $50(32.3)$ & $209(36.4)$ & \multirow[t]{2}{*}{1.58} & \multirow[t]{2}{*}{ NS } \\
\hline & & Ext & $260(62.1)$ & $105(67.7)$ & $365(63.6)$ & & \\
\hline \multirow[t]{2}{*}{8} & \multirow{2}{*}{$\begin{array}{l}\text { Whatever goes wrong with } \\
\text { my health is my own fault }\end{array}$} & Int & $247(58.9)$ & $95(61.3)$ & $342(59.6)$ & \multirow[t]{2}{*}{.26} & \multirow[t]{2}{*}{ NS } \\
\hline & & Ext & $172(41.1)$ & $60(38.7)$ & $232(40.4)$ & & \\
\hline \multirow[t]{2}{*}{9} & & Int & $93(22.2)$ & $31(20.0)$ & $124(21.6)$ & .32 & NS \\
\hline & $\begin{array}{l}\text { to let nature run its own } \\
\text { course }\end{array}$ & Ext & $326(77.8)$ & 124(80.0) & $450(78.4)$ & & \\
\hline 10 & Health professionals keep & Int & $126(30.1)$ & $46(29.7)$ & $172(30.0)$ & .08 & NS \\
\hline & me healthy & Ext & 293(69.9) & 109(70.3) & $402(70.0)$ & & \\
\hline 11 & When I stay healthy I'm just & Int & $76(18.1)$ & $25(16.1)$ & $101(17.6)$ & .31 & NS \\
\hline & plain lucky & Ext & $343(81.9)$ & $130(83.9)$ & $473(82.4)$ & & \\
\hline 12 & My physical well-being & Int & $375(89.5)$ & $136(87.7)$ & $511(89.0)$ & .36 & NS \\
\hline & $\begin{array}{l}\text { depends on how well I take } \\
\text { care of myself }\end{array}$ & Ext & $44(10.5)$ & $19(12.3)$ & $63(11.0)$ & & \\
\hline 13 & When I feel ill I know it is & Int & $222(53.0)$ & $78(50.3)$ & $300(52.3)$ & .32 & NS \\
\hline & $\begin{array}{l}\text { because I have not been } \\
\text { taking care of myself } \\
\text { properly }\end{array}$ & Ext & $197(47.0)$ & $77(49.7)$ & $274(47.7)$ & & \\
\hline 14 & The type of care I receive & Int & $187(44.6)$ & $61(39.4)$ & $248(43.2)$ & 1.28 & NS \\
\hline
\end{tabular}




\begin{tabular}{|c|c|c|c|c|c|c|c|}
\hline & $\begin{array}{l}\text { from other people is what is } \\
\text { responsible for how well I } \\
\text { recover from an illness }\end{array}$ & Ext & $232(55.4)$ & $94(60.6)$ & $326(56.8)$ & & \\
\hline \multirow[t]{2}{*}{15} & \multirow{2}{*}{$\begin{array}{l}\text { Even when I take care of } \\
\text { myself it is easy to get sick }\end{array}$} & Int & $69(16.5)$ & $17(11.0)$ & $86(15.0)$ & \multirow[t]{2}{*}{2.69} & \multirow[t]{2}{*}{ NS } \\
\hline & & Ext & $350(83.5)$ & $138(89.0)$ & $488(85.0)$ & & \\
\hline \multirow[t]{2}{*}{16} & \multirow{2}{*}{$\begin{array}{l}\text { When I become ill it's a } \\
\text { matter of fate }\end{array}$} & Int & $82(19.6)$ & $33(21.3)$ & $115(20.0)$ & \multirow[t]{2}{*}{.21} & \multirow[t]{2}{*}{ NS } \\
\hline & & Ext & $337(80.4)$ & $122(78.7)$ & $457(80.0)$ & & \\
\hline \multirow[t]{2}{*}{17} & \multirow{2}{*}{$\begin{array}{l}\text { I can pretty much stay } \\
\text { healthy by taking good care } \\
\text { of myself }\end{array}$} & Int & $364(86.9)$ & $136(87.7)$ & $500(87.1)$ & \multirow[t]{2}{*}{$.05 *$} & \multirow[t]{2}{*}{ S } \\
\hline & & Ext & $55(13.1)$ & 19(12.3) & 74(12.9) & & \\
\hline \multirow[t]{2}{*}{18} & \multirow{2}{*}{$\begin{array}{l}\text { Following doctor's orders to } \\
\text { the letter is the best way for } \\
\text { me to stay healthy }\end{array}$} & Int & $242(57.8)$ & $96(61.9)$ & $338(58.9)$ & \multirow[t]{2}{*}{.82} & \multirow[t]{2}{*}{ NS } \\
\hline & & Ext & $177(42.2)$ & $59(38.1)$ & $236(41.1)$ & & \\
\hline
\end{tabular}

\section{*: Significant at 0.05 level; NS: Statistically not significant}

Table 4 reveals the relationship between the health locus of control of substance users and non- substance users. The chi-square and the level of significance show that there was no significant difference between in the health locus of control of substance users and non- substance users in 16 of the 18 items. Therefore, the hypothesis was rejected for the 16 items and accepted for items 3 and 17.

\section{DISCUSSION}

Substance use during the university years is a significant public health concern in Nigeria. This study was set to determine if there is a significant difference in the health locus of control of substance users and nonusers and to find out if substance users subscribe to external health locus of control. This study revealed there was no significantdifference in thehealth locus of control of substance users and non- substance usersin 16 of the 18 items. There was however a statistically significant difference between substance users and non-users in only two items. In item 3 which says "if I see an excellent doctor regularly, I am less likely to have a health problem" $(\mathrm{p}=0.02)$, and in item 17 which says, "I can pretty much stay healthy by taking good care of myself" $(\mathrm{p}=0.05)$.

Another finding revealed that substance users were not more inclined to externality than non-substance users. In this study, non-users subscribed to chance and powerful others as much as the substance users. This however is in contrasts others studies such as Bush \& Iannotti (1991) and Omobude-Idiado (1998). Bush \& Iannotti (1991) reported that there was a significant relationship between college drug users and External Health Locus of Control (EHLC) while Omobude-Idiado (1998) reported that stimulant users were more inclined to externality with a higher percent inclined to Chance Health Locus of Control (CHLC) scale than Powerful Others (PHLC) scale. On non-users, Omobude-Idiado (1998) reported that they were basically internalizers.In this study, of the six items under the internal health locus of control (IHLC), non-substance users scored higher percentage in internality than substance users in items 6,8 and 17. Conversely, substance users recorded higher percentage of internalization in items 1,12 , and 13. Non-substance users scored higher percentage in four of the six items under the chance health locus of control (CHLC) while substance users scored higher percentage in items 4 and 16. The same trend repeated itself under the powerful others scale. In a study by Manganiello (1978), substance abusers were significantly more externally oriented in their locus of control than the nonaddict control group. It was demonstrated that one's propensity to attribute the positive outcomes of events to external factors is correlated with increased risk for developing addictive behaviours. The present study did not support the hypothesis that substance users subscribe to externality.

\section{CONCLUSION}

Health locus of control is a construct that consists of factors that influence and contribute to individual's belief in relation to the extent to which he or others can influence life events. The findings of this study contradicted some of the established findings that substance users are "externalizers" who subscribe to powerful others such as the type of care I receive from other people is what is responsible for how well I recover from an illness and chance, such as when I stay healthy, I am just plain lucky.There is therefore no clear indication in this study that substance users are externalizers. Therefore, this study has implications on the two groups of participants. The implications concerns health education and counselling. The two groups need information on health issues because almost all the participants subscribed to externality. They need information and counsel on believing in their capacity to control their health which will consequently lead to seeking health information on how to prevent ill-health. 


\section{REFERENCES}

[1] Adekeye, O. A., Adeusi, S. O., Chenube, O. O., Ahmadu,F. O.\& Sholarin,M. A. (2015). Assessment of Alcohol and Substance Use among Undergraduates in Selected Private Universities in Southwest Nigeria. IOSR Journal of Humanities and Social Science (IOSR-JHSS) Vol. 20 (3): 1-7.

[2] Allahverdipour, H., MacIntyre, R., Hidarnia, A.,Shafii, F., Kazemnegad, A., Geleiha, A.,and Emami, A. (2007). Assessing protectivefactors against drug abuse among highschool students: Self-control and the extendedparallel process model. J AddictNurs, 18(2): 65-73.

[3] Bush, P. and Iannotti, R. (1985). The development of children's health orientation and behaviours: Lessons for substance use prevention. NIDA Research Monograph Series, 56: 45-74.

[4] Carton, J. S. and Nowicki, S. (1994). Antecedents of individual differences in locus of control of reinforcement: A critical review. Genetic, Social, \& General Psychology Monographs, 120(1), 31-81.

[5] Clarke, J. H., MacPherson, B. V., andHolmes, D. R. (1982). Cigarette smoking and external locus of controlamong young adolescents. J Health Soc Behav 23:253-259.

[6] Cohen, M. and Azaiza, F. (2007). Health-promoting behaviorsand health locus of control from amulticultural perspective. Ethn Dis. 17(4):636-642.

Danielsson, A.K., Wennberg, P., Tengstrom, A., andRomelsjo, A. (2010). Adolescent alcohol use trajectories: Predictors and subsequent problems. Addictive Behaviors, 35, 848-852.

[7] Hill, D. J., and Bale, R. M. (1980). Development of the Mental Health Locus of Control and Mental Health Locus of Origin Scales. Journal of Personality Assessment, 44, 148-156.

[8] Hingson, R.W., Zha, W., Weitzman, E.R. (2009). Magnitude of and trends in alcohol-related mortality and morbidity among U.S. college students ages 18-24, 1998-2005. Journal of Studies on Alcohol \& Drugs, S16, 12-20.

[9] Jessor, R., Collins, M. I., andJessor, S. J. (1972). On becoming a drinker: Social-psychological aspects of anadolescent transition. Ann NY Acad Sci 197:199-222.

[10] Lefcourt, H.M. (1991). Locus of control. In J. P. Robinson, P.R. Shaver, and L.S.Wrightsman, (Eds.), Measures of personality and social psychological attitudes (pp. 413-499).San Diego: Academic Press.

[11] Lefcourt, H. M. (1982). Locus of control: Current trends in theory and research (2nd Ed.). Hillsdale, NJ: Erlbaum.

[12] Levenson, H. (1981). Differentiating among internality, powerful others, and chance. In H.M. Lefcourt (Ed.) Research with the locus of control concept (Vol.1, pp. 15-63). New York: Academic Press.

[13] Manganiello, J. A. (1978). Opiate Addiction: A Study Identifying Three Systematically Related Psychological Correlates. The International Journal of the Addictions, 13.5, 839-847.

[14] Miller, J.W., Naimi, T.S., Brewer, R.D., andJones, S.E. (2007). Binge drinking and associated health risk behaviors among high school students. Pediatrics, 119, 76-85.

[15] ].Miller, P. C., Lefcourt, H. M., \& Ware, E. E. (1983). The construction and development of the Miller Marital Locus of Control Scale. Canadian Journal of Behavioural Science, 15, 266-279.

[16] Newcomb, M.D., and Locke, T. (2005). Health, social, and psychological consequences of drug use and abuse. In: Sloboda, Z. (Ed.) Epidemiology of drug abuse (pp. 45-59). New York: Springer, 2005.

[17] Omobude-Idiado, S. N. (1998). Locus of control of health beliefs among undergraduate stimulant users and non-users. The Nigerian Journal of Guidance and Counselling, 6(1\&2): 175-187.

[18] Rotter, J. B. (1990). Internal versus external control of reinforcement: A case history of a variable. American Psychologist, 45(4), 489-493.

[19] Sneed, C. D., Morisky, D. E., Rotheram-Borus,M. J., Ebin, V. J., and Malotte, C. K. (2001). Patternsof adolescent alcohol, cigarette, and marijuana use over a 6-month period.Addict Behav, 26: 415-23.

[20] Spalding, A. D. (1995). Racial minorities and other highriskgroups with HIV and AIDS at increasedrisk for psychological adjustment problems inassociation with health locus of control orientation.SocWork Health Care. 21:81-114.

[21] Townsend, L., Flisher, A.J., and King, G. (2007). A systematic review of the relationship between high school dropout and substance use. Clinical Child \& Family Psychology Review, 10, 295-317.

[22] Wallston, K.A., and Wallston, B.S. (1981). Health locus of control scales. In H.M. Lefcourt(Ed.), Research with the locus of control construct, 1, 189-243, New York, NY: Academic.

[23] Wallston, K. A., Wallston, B. S., and DeVellis, R. (1978). Development of the Multidimensional Health Locus of Control (MHLC) scales. Health Education Monographs, 6, 160-170. 